\title{
Pengaruh Kondisi Penyimpanan Dan Kadar Air Awal Biji Kakao (Theobroma cacao L) Terhadap Pertumbuhan Jamur
}

\author{
Nurhaya Kusmiah \\ Program Studi Agribisnis, Universitas Al Asyariah Mandar \\ nurhayakusmiah@gmail.com
}

\begin{abstract}
Abstrak
Kadar jamur merupakan jumlah biji berjamur dalam 100 biji selama penyimpanan, kadar jamur dipengaruhi oleh kondisi penyimpanan yang digunakan, seperti kelembaban dan suhu pada kotak penyimpanannya. Penelitian ini bertujuan untuk mengidentifikasi kadar jamur bagian luar dan dalam pada biji kakao yang disimpan pada 2 jenis penyimpanan yaitu kotak penyimpanan menggunakan sirkulasi (exhaust), dan AC $25^{\circ} \mathrm{C}$ selama 3 bulan penyimpanan, biji kakao yang digunakan yaitu biji kakao tanpa fermentasi dan yang telah difermentasi selama 3 hari, dengan kadar air awal $7 \%$ dengan menggunakan wadah plastik dan karung goni pada masing - masing sampel. Berdasarkan pengujian yang dilakukan diperoleh kadar jamur paling rendah yaitu biji kakao pada kotak penyimpanan menggunakan $\mathrm{AC}$ dengan suhu $25^{\circ} \mathrm{C}$, karena pada penyimpanan ini $\mathrm{RH}$ dapat dipertahankan sekitar $70 \%$ dan suhu juga sangat rendah mengakibatkan jamur tidak mudah berkembang
\end{abstract}

Keywords : Kakao, Jamur, Penyimpanan, Goni, Plastik

\section{Pendahuluan}

Indonesia adalah salah satu negara yang mengandalkan kegiatan perdagangan internasional sebagai penggerak dalam pertumbuhan ekonomi. Selain berperan dalam mendatangkan devisa negara, dengan melakukan perdagangan internasional maka akan membangun jaringan bisnis global dan bisa selalu mengikuti perkembangan produk dan industri di pasar internasional.

Sektor pertanian di Indonesia menghasilkan berbagai jenis komoditas. Salah satu komoditas hasil pertanian Indonesia yaitu biji kakao dimana Indonesia merupakan peringkat ke-3 sebagai Negara penghasil kakao terbesar di dunia setelah pantai gading dan Ghana. Biji kakao termasuk komoditas andalan dalam kegiatan ekspor Indonesia hal ini dikarenakan biji kakao di Indonesia memiliki beberapa kelebihan seperti cita rasa yang khas dan titik leleh yang lebih tinggi.

Dengan kondisi ekonomi Indonesia saat ini yang cukup stabil, menjadikan industry kakao berpeluang besar sebagai pemasok kebutuhan bahan baku untuk pasar domestic dan global. Kebangkitan dan berkembangnya kapasitas pengolahan industry kakao nasional serta masuknya beberapa investor asing yang masuk ke Indonesia di sektor kakao dapat menunjang, keberlanjutan perkakaoan Indonesia dari sudut produktivitas maupun mutunya.

Biji buah kakao/coklat yang telah difermentasi dijadikan serbuk yang disebut sebagai coklat bubuk. Coklat ini dipakai sebagai bahan untuk membuat berbagai macam produk makanan dan minuman. Buah coklat/kakao tanpa biji dapat difermentasi untuk dijadikan pakan ternak. Biji kakao dapat diproduksi menjadi empat jenis produk kakao setengah jadi seperti cocoa liquor, cocoa butter, cocoa cake, cocoa powder dan cokelat. Pasar cokelat merupakan konsumen terbesar dari biji kakao dan produk setengah jadi jadi seperti cocoa powder dan cocoa butter.

Kakao atau cokelat merupakan tanaman industri perkebunan, yang telah menjadi komoditi yang penting di Indonesia sejak tahun 1951. Pemerintah Indonesia mulai menaruh perhatian dan mendukung industri kakao pada tahun 1975, setelah PT Perkebunan VI berhasil menaikkan produksi kakao per hektar melalui penggunaan bibit unggul Upper Amazon Interclonal Hybrid, yang merupakan hasil persilangan antar klon dan sabah. Tanaman tropis tahunan ini berasal dari Amerika Selatan. Penduduk Maya dan Aztec di Amerika Serikat dipercaya sebagai perintis pengguna kakao dalam makanan dan minuman. Sampai pertengahan abad ke XVI, selain bangsa di Amerika Selatan, hanya bangsa Spanyol yang mengenal tanaman kakao. Dari Amerika Selatan tanaman ini menyebar ke Amerika Utara, Afrika dan Asia (Wahyudi, 2008).

Biji kakao yang telah melewati tahap penanganan pasca panen selanjutnya disimpan sebelum diolah menjadi coklat, selama penyimpanan tersebut berlangsung akan terjadi penurunan nilai ekonomis disebabkan oleh adanya pertumbuhan jamur selama penyimpanan, hal ini menyebabkan kualitas mutu biji kakao akan sangat rendah sehingga nilai ekonomis pun menurun.

Berdasarkan permasalahan tersebut maka diperlukan adanya penelitian tentang penyimpanan biji kakao yang menggunakan kondisi penyimpanan yang berbea-beda untuk mengetahui penyimpanan yang optimal dapat menekan tingkat pertumbuhan jamur pada biji kakao. 


\section{Metodologi}

Metode yang digunakan dalam penelitian ini yaitu uji cut test dengan sumber data primer yang diperoleh dari pengamatan kadar biji berjamur dalam 100 biji kakao setiap 7 hari sekali selama 3 bulan penyimpanan. Paremeter yang diamati dalam penelitian ini adalah pertumbuhan jamur luar dan jamur dalam biji kakao setiap minggu, kadar air biji kakao setiap minggu dan kelembaban kotak penyimpanan.

Keberadaan jamur pada setiap biji diidentifikasi kemudian data dua kali ulangan dirata-ratakan dan persentase biji berjamur dihitung sebagai berikut:

$$
\text { Biji berjamur }(\%)=\frac{\text { Jumlah bijiberjamur }}{100} \times 100 \%
$$

Penelitian ini dilakukan dengan menggunakan sampel biji kakao yang telah difermentasi selama 3 hari dan tanpa fermentasi dengan kadar air sampel 7\% yang disimpan pada dua jenis penyimpanan yaitu menggunakan AC dengan set suhu $25^{\circ} \mathrm{C}$ dan menggunakan exhaust (sirkulasi), dimana ukuran tempat penyimpanan sebesar $1.5 \times 3$ meter.

Selain pengukuran kadar jamur, juga dilakukan pengukuran suhu dan kelembaban yang terapat dalam kotak penyimpanan selama 3 bulan menggunakan sensor suhu dan senor RH (Kelembaban), selain itu juga dilakukan pengukuran kadar air sampel dari awal penyimpanan setiap minggu hingga akhir penyimpanan.

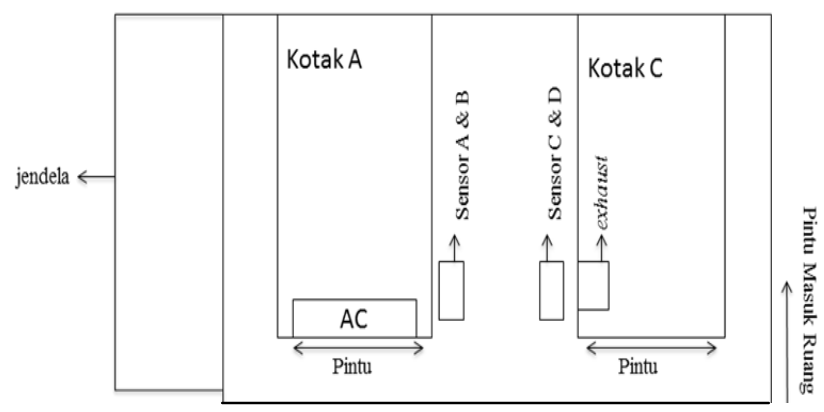

Gambar 1. Kotak Penyimpanan

Kotak penyimpanan yang digunakan terbuat dari tripleks dengan ketebalan $\pm 2 \mathrm{~cm}$, dan luas ruangan \pm 6 $\mathrm{m}^{2}$. Suhu penyimpanan (exhaust) diperkirakan $\pm 30-31$ ${ }^{\circ} \mathrm{C}$ pada kondisi normal. Kotak penyimpanan menggunakan $\mathrm{AC} 25^{\circ} \mathrm{C}$ yang juga terletak didekat jendela ruang penyimpanan. Sedangkan Air Conditioner (AC) diletakkan didekat pintu masuk kotak penyimpanan, dan sensor pengukur kelembaban terletak di luar kotak, dimana 1 sensor mengukur 2 kotak, sehingga menggunakan 2 sensor

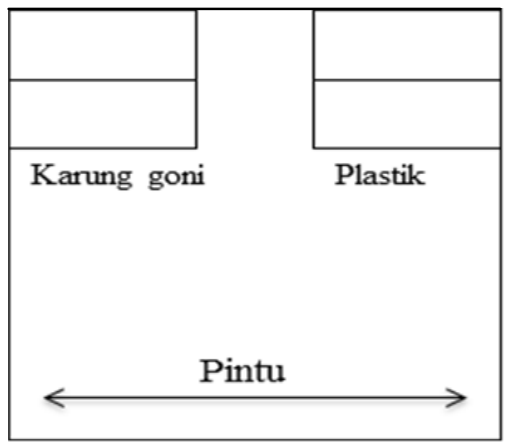

Gambar 2. Letak Sampel Dalam Ruang

Letak penyimpanan sampel untuk pengujian kadar jamur didalam kotak berada di bagian belakang, berjejer antara karung dengan plastik

\section{Hasil}

Kadar Air Sampel Penyimpanan Exhaust

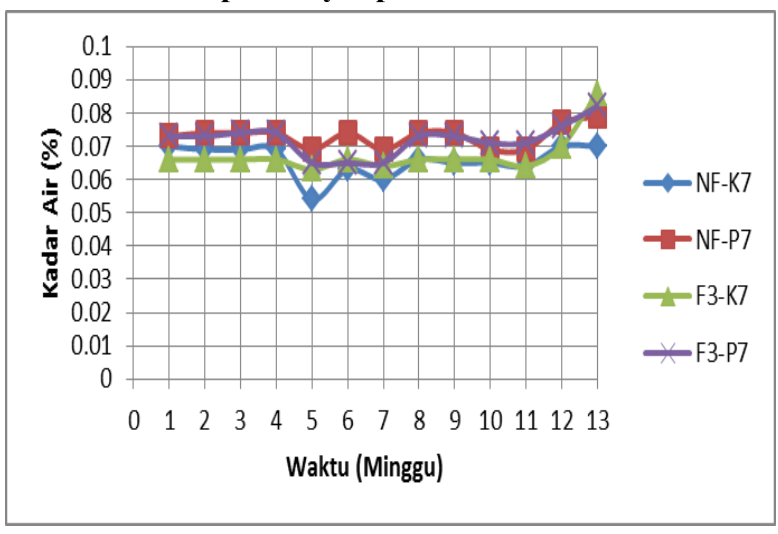

Gambar 3. Kadar Air Peny. Exhaust

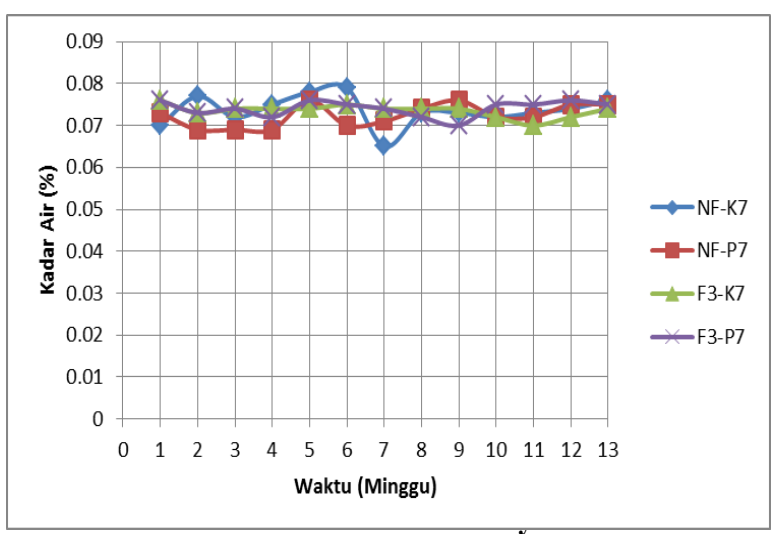

Pada penyimpanan menggunakan exhaust kadar air biji fermentasi 3 hari menggunakan Karung Goni kadar airnya cenderung konstan hingga minggu ke-11 namun pada minggu selanjutnya kadar air biji kemudian meningkat hingga $8 \%$ begitupun dengan sampel biji kakao tanpa fermentasi menggunakan karung goni, penurunan kadar air hanya terjadi pada minggu ke-5 namun mengalami peningkatan pada minggu terakhir.

Berbeda dengan kadar air sampel tanpa fermentasi dan fermentasi 3 hari menggunakan karung goni dan 
plastik cenderung meningkat hingga minggu akhir penyimpanan

\section{Kadar Jamur Sampel Penyimpanan Exhaust}

a. Kadar Jamur Kulit Biji Kakao

Pada pengujian ini dilakukan pengambilan sampel sebanyak 100 biji secara acak lalu mengamati jamur yang terdapat pada bagian luar biji.

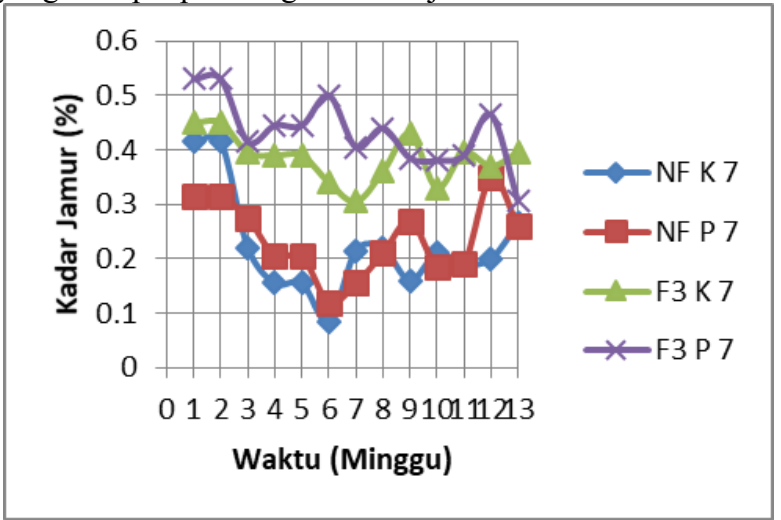

Gambar 5. Kadar Jamur Kulit Peny. Exhaust

Berdasarkan grafik diatas, data menunjukkan bahwa pada penyimpanan sirkulasi kadar jamur yang terdapat pada kulit biji kakao paling banyak dijumpai pada sampel biji kakao yang telah difermentasi menggunakan wadah plastik, berbeda dengan sampel Non fermentasi menggunakan Karung goni, dimana pertumbuhan jamurnya sedikit dan terus mengalami penurunan.

\section{b. Kadar Jamur Bagian Dalam Biji}

Pada pengujian kadar jamur biji kakao bagian dalam, dilakukan dengan membelah dua biji kakao lalu mengamati jamur yang terdapat pada bin biji, dimana pengujian ini dilakukan sebanyak dua kali.

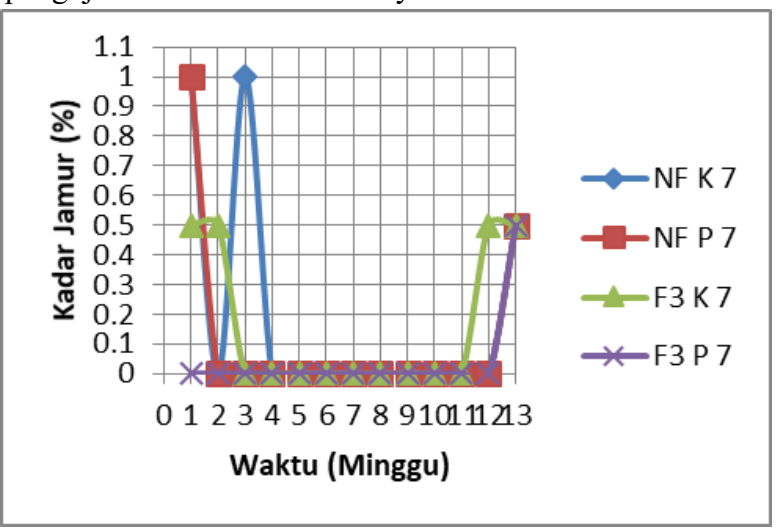

Gambar 6. Kadar Jamur bin Peny. Exhaust

Sedangkan untuk kadar jamur bagian dalam biji kakao diperoleh data yang menunjukkan bahwa kadar jamur bagian dalam biji paling sedikit terdapat pada sampel non fermentasi menggunkan karung goni dimana hingga akhir penyimpanan tidak terjadi peningkatan pertumbuhan jamur.

\section{Kadar Jamur Sampel Penyimpanan $A C 25^{\circ} C$}

\section{a. Kadar Jamur Kulit Biji Kakao}

Pada pengujian ini dilakukan dengan menyimpan sampel pada ruang dengan menggunakan AC dengan pengaturan suhu $25{ }^{\circ} \mathrm{C}$ lalu dilakukan pengujian setiap seminggu sekali untuk mengamati pertumbuhan jamur yang ada di bagian kulit dan bagian dalam biji.

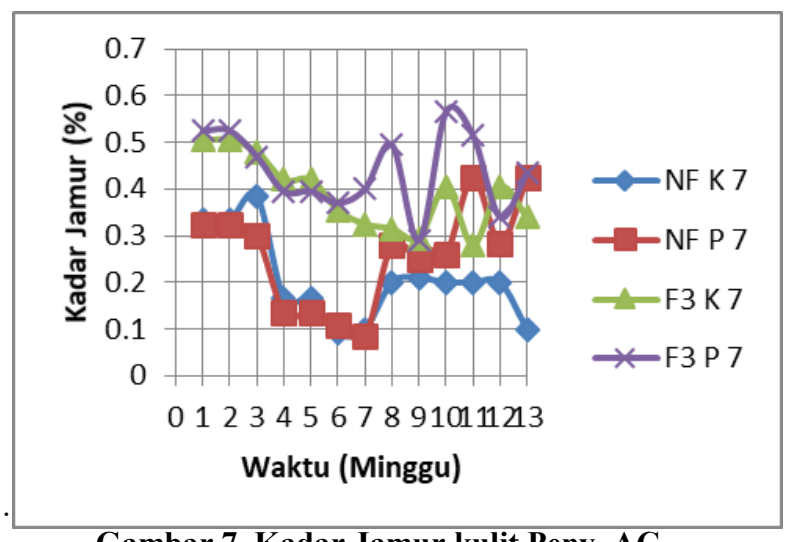

Gambar 7. Kadar Jamur kulit Peny. AC

Kadar jamur kulit pada biji kakao dalam penyimpanan ini paling banyak pada sampel non fermentasi menggunkan wadah plastik dimana jamur yang tumbuh hingga akhir penyimpanan bisa dikatakan meningat begitupun dengan sampel non fermentasi menggunakan wadah plastik terus.

Berbeda dengan sampel yang menggunakan wadah plastik terlihat pertumbuhan jamur hingga akhir penyimpanan cenderung menurun, dan penurunan yang angat drastis pada sampel Non fermentasi menggunakan karung goni.

\section{b. Kadar Jamur Bagian Dalam Biji Kakao}

Berdasarkan uji cut test yang dilakukan terhadap petumbuhan jamur pada biji kakao, diperoleh data yang menunjukkan bahwa pertumbuhan jamur paling kecil yaitu pada sampel non fermentasi menggunakan wadah karung goni, dimana penurunan kadar jamur dimulai pada minggu ke 3 higga minggu akhir penimpanan, sedangkan untuk pertumbuhan jamur yang cukup besar terdapat pada sampel biji kakao fermenai 3 hari dengan menggunakan wadah plastik dimana pertumbuhan jamur lbih besar diakhir penyimpanan.

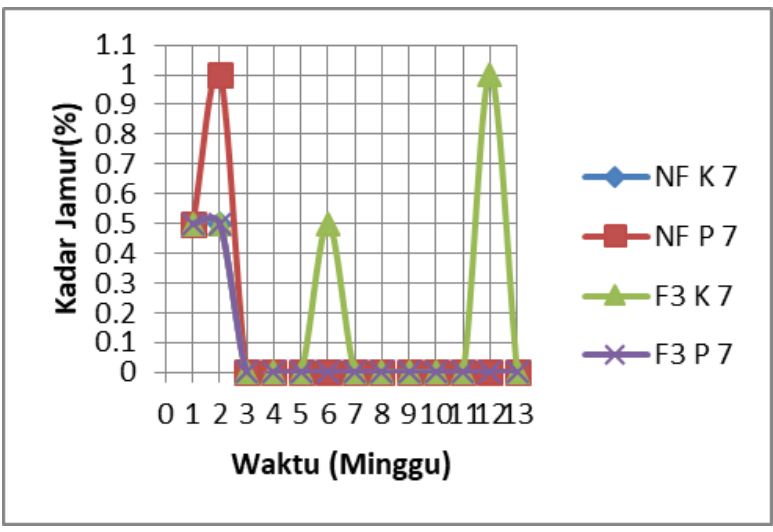

Gambar 8. Kadar Jamur bin Peny. AC

Kadar jamur kulit dan bin (bagian dalam) sampel pada penyimpanan menggunakan AC $25{ }^{\circ} \mathrm{C}$ terlihat lebih 
sedikit dibandingkan dengan penyimpanan menggunakan pendingin exhaust, perbedaan pertumbuhan jamur ini terjadi akibat adanya perbedaan kelembaban dan suhu pada kota penyimpanan, juga dipengaruhi oleh wadah yang digunakan.

Berdasarkan peneltian yang telah dilakukan selama 3 bulan penyimpanan diperoleh hasil yang menunjukkan bahwa penyimpanan yang mampu menekan mpertumbuhan jamur pada biji kakao yaitu dengan menggunakan kotak pnyimpanan $\mathrm{AC}$ suhu $25^{\circ} \mathrm{C}$, dimana biji kakao yang paling baik adalah tanpa fermentasi dan dikemas dalam wadah karung goni.

Data yang diperoleh menunjukkan bahwa penggunaan wadah, karakteristik biji kakao, suhu dan kelembaban kotak penyimpanan dapat mempengaruhi kualitas mutu biji kakao khususnya pada pertumbuhan jamur. Dimana pada penggunaan wadah plastik sampel cenderung basah karena pada dasarnya bahan plastik tidak menyerap air, sehingga ketika sampel berair diakibatkan uap panas dari dalam kotak maka air akan tersimpan didalam plastik dan lama kelamaan akan diserap oleh bahan menyebabkan bahan biji kakao kadar airnya meningkat dan terjadi pertumbuhan jamur. Berbeda dengan penggunaan karung goni, dimana bahan karung kain dan kering yang mampu menyerap air ketika ada basah didalam sampel sehingga sampel dapat terjaga kadar airnya dan tidak lembab secara dapat menekan pertumbuhan jamur, namun kelemahan dari wadah karung goni yaitu ketika ada air dari luar (tersiram) maka air tersebut dapat terserap oleh kain dari karung goni (basah), berbeda dengan plastik, ketika sampel tersiram maka air tidak dapat masuk kedalam wadah, dalam wadah, dalam artian sampel aman dari siraman air.

\section{Perbandingan Suhu dan Kelembaban}

\section{a. Kotak Penyimpanan exhaust}

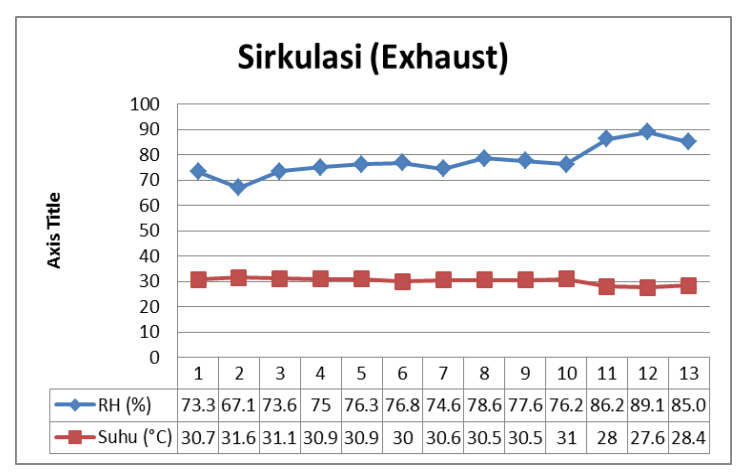

Grafik menunjukan perubahan kelembaban

\section{Gambar 9. Suhu \& Kelembaban}

Kelembaban pada penyimpanan ini diukur menggunakan sensor suhu LM35, yang dimana pengukuran sensor dilakukan setiap 5 menit alat akan mencatat suhu yang terjadi dalam ruang prnyimpanan, sehingga perubahan yang sangat kecil pada suhu ruang akan terlihat.

Berdasarkan pengukuran suhu yang dilakukn diperoleh data yang menunjukkan bahwa suhu pada kotak penyimpanan ini cenderung stabil hingga minggu ke 10 , namun akhir penyimpanan terlihat suhu sedikit menurun sebesar $2{ }^{\circ} \mathrm{C}$. Sedangkan untuk kelembaban pada ruang penyimpanan ini cenderung meningkat hingga minggu akhir.. Kelembaban tertinggi pada penyimpanan ini yaitu $89 \%$. Tingginya kelembaban kotak dipengaruhi oleh kelembaban di luar kotak, karena exhaust bekerja mengeluarkan udara dalam penyimpanan dan saat bersamaan memasukkan udara yang ada diluar kotak, sehingga jika udara diluar penyimpanan lembab maka udara dalam kotak juga akan lembab. Sehingga secara keseluruhan dapat dikatakan bahwa pada ruang penyimpanan menggunakan exhaust suhu dapat dipertahankan namun tidak begtu efisien dan begitupun dengan kelembaban yang terjadi didalam ruang penyimpanan ini cenderung meningkat, hal ini disebabkan oleh prinsip kerja dari exhaust dimana udara pana yang berasal dari dalam ruang akan dikeluarkan namun udara dingin atau panas dari luar ruang akan dimasukkan, jika kondisi cuaca diluar ruang lembab seperti terjadinya hujan berkepanjangan maka udara dalam ruangan ini juga akan lembab seperti kondisi cuaca diluar ruangan, selain itu kelembaban ruangan ini juga dapat dipengaruhi oleh terbukanya pintu dan padamnya listrik, maka kelembaban yang terjadi didalam ruang penyimpanan akan berpengaruh terhadap pertumbuhan jamur pada sampel biji kakao, dimana semakin lembab suatu ruang maka pertumbuhan jamur juga akan semakin tinggi.

\section{b. Kotak Penyimpanan $\mathrm{AC} 25^{\circ} \mathrm{C}$}

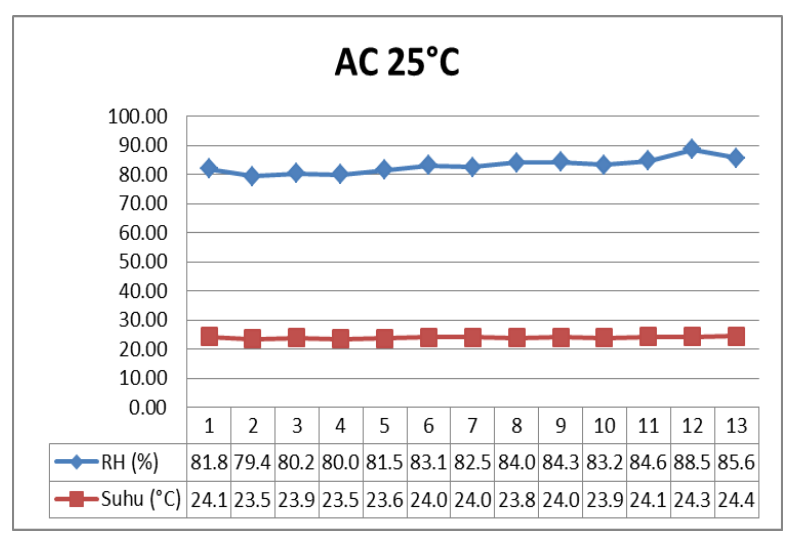

\section{Gambar 10. Suhu \& Kelembaban}

Kotak penyimpanan yang menggunakan AC dengan suhu setting $25{ }^{\circ} \mathrm{C}$, dari pengamatan suhu dapat disimpulkan bahwa suhu yang terjadi dalam penyimpanan ini hampir stabil, perubahan suhu terjadi sangat kecil $1{ }^{\circ} \mathrm{C}$, terlihat dari grafik bahwa dari minggu awal hingga minggu akhir penyimpanan suhu dapat terjaga dengan konstan.

Sedangkan untuk pengamatan kelembaban daam kotak penyimpanan, data menunjukkan bahwa ke RH daam ruang cukup stabil, dimana $\mathrm{RH}$ meningkat drastis pada minggu ke 12 sebesar $88 \%$ namun kembali normal hingga minggu akhir.

Berdasarkan kelembaban awal hingga akhir terlihat bahwa nilai kelembaban memang cukup tinggi, sekitar \pm $80 \%$, kelembaban yang tinggi pada penyimpanan ini juga dipengaruhi oleh kelembaban di luar kotak 
penyimpanan, yang bisa disebabkan oleh beberapa faktor seperti padamnya listrik. Secara keselurahan dapat disimpulkan bahwa ruang penyimpanan yang menggunakan $\mathrm{AC}$ suhu $25{ }^{\circ} \mathrm{C}$ dapat mempertahankan suhu tetap stabil dan juga memberikan kelembaban yang rendah serta cukup stabil dari awal hingga akhir, seperti prinsip kerja dari AC dimana udara panas dalam ruang dikeluarkan tanpa memasukkan udara dari luar dalam artian AC mendinginkan udara dengan menggunakan refrigerator sehingga bagaimanapun kondisi cuaca diluar ruangan seperti hujan atau pana terik tidak akan mempengaruhi kelembaban dan suhu dalam kotak penyimpanan, kondisi dari biji kakao pun dapat dijaga, selain itu dengan menggunakan AC suhu dan kelembaban dalam ruang hanya terpengaruh pada kegiatan pembukaan pintu dan padamnya listrik.

\section{Kesimpulan}

1. Kadar biji berjamur bagian dalam biji selain dipengaruhi oleh kelembaban juga sangat dipengaruhi oleh integritas kulit biji, semakin rapuh kulit biji maka bagian dalam biji kakao akan sangat mudah terserang jamur

2. Penyimpanan optimal yang mampu mengurangi tingkat pertumbuhan jamur yaitu penyimpanan yang dapat mengatur kelembaban ruangan maksimal 70\%, yaitu penyimpanan dengan $\mathrm{AC} 25^{\circ} \mathrm{C}$

3. Kadar air awal bijii kakao sebelum peyimpanan sangat mempengaruhi kadar biji berjamur selama proses penyimpanan berlangsung

4. Pertumbuhan jamur pada biji kakao dapat ditekan dengan menggunakan wadah karung goni

\section{Daftar Pustaka}

Anonimous, 1993, Pengolahan kakao, Direktorat Jenderal Perkebunan Departemen Pertanian RI.

Aroyeun, S.O. danG.O. Adegoke. 2006. Reduction of ochratoxin A (OTA) in spiked cocoa powder and beverage using aqueous extracts and essential oils of Aframomum danielli. Afr. J. Biotechnol. 6:612-616.

Asrul, 2009, Populasi Jamur Mikotoksigenik dan Kandungan Aflatoksin pada Beberapa Contoh Biji Kakao (Theobroma cacao L) Asal Sulawasi Tengah.

Badrun, M. 1991. Program Pengembangan Kakao di Indonesia.Prosiding Komperensi Nasional Kakao III, Medan. Buku 2 : 1-9

Bahri, Syamsul., 2002. Bercocok Tanaman Perkebunan Tahunan. Gadjah Mada University Press, Yogyakarta.

Balitbang Pertanian, 2005. Prospek dan Arah Pengembangan Agribisnis Kakao Indonesia. Badan Penelitian dan Pengembangan Pertanian, Departemen Pertanian.

Rahmat. 2010. Bagian-Bagian Biji Kakao. Panduan Lengkap Pengolahan Biji Kakao. 2010. Makassar 27 Januari 2014
Raper, K.B., dan D.I. Fennel. 1977. The genus Aspergillus.Robert E. Krieger. Pub. Company. Huntington. New York.

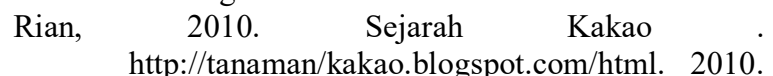
Makassar 27 Januari 2014

Sri Mulato, S., Widyotomo, S., Misnawi dan Suharyanto, E., 2009. Petunjuk Teknis Pengolahan Produk Primer dan Sekunder Kakao. Pusat Penelitian Kopi dan Kakao Indonesia, Jember.

Suryatmi Retno Dumadi.2011. the moisture content increase of Centre of Agroindustrial Technology, BPPT, Jakarta

Susanto.Fx.1994.Tanaman kakao:budidaya dan penglahan hasil.kanisius Yogyakarta

Syarief, R., S.Santausa, St.Ismayana B. 1989. Teknologi Pengemasan Pangan.Laboratorium Rekayasa Proses Pangan, PAU Pangan dan Gizi, IPB.

Tjitrosoepomo, Gembong, 1988, Taksonomi Tumbuhan (Spermathopyta), Yogyakarta : Universitas Gadjah Mada.

Wahyudi , dkk.2008.Panduan lengap pengolahan kakao.Swadaa:jakarta

Yunasfi, 2008. fungi at eucalyptus urophylla s.t. blake in log yard (tpk) pt. toba pulp lestrari, tbk. kabupaten toba samosir north sumatera Departemen Kehutanan. 